\title{
Field work in 1986 in the Fiskefjord area, southern West Greenland
}

\author{
A. A. Garde, S. B. Jensen and M. Marker
}

Field mapping of Archaean basement rocks for the Fiskefjord map sheet at the scale 1:100 000, initiated in 1980 (Garde \& McGregor, 1982; Garde, 1984, 1986), was continued by four teams in June-August 1986. The authors worked along the outer coast and in the vicinity of Fiskefjord (fig. 1) supported by rubber dinghies and the GGU cutter J. F. Johnstrup. Mapping around the lake Quagssûp taserssua and reconnaissance mapping on the northern parts of Bjørneøen and Storø was supported by a Bell Jet Ranger helicopter. V. R. McGregor continued his mapping at the south-western corner of the map sheet area for three weeks in August.

A stream sediment sampling programme for heavy minerals derived from the supracrustal rocks was carried out along with the geological mapping. The samples indicate that the

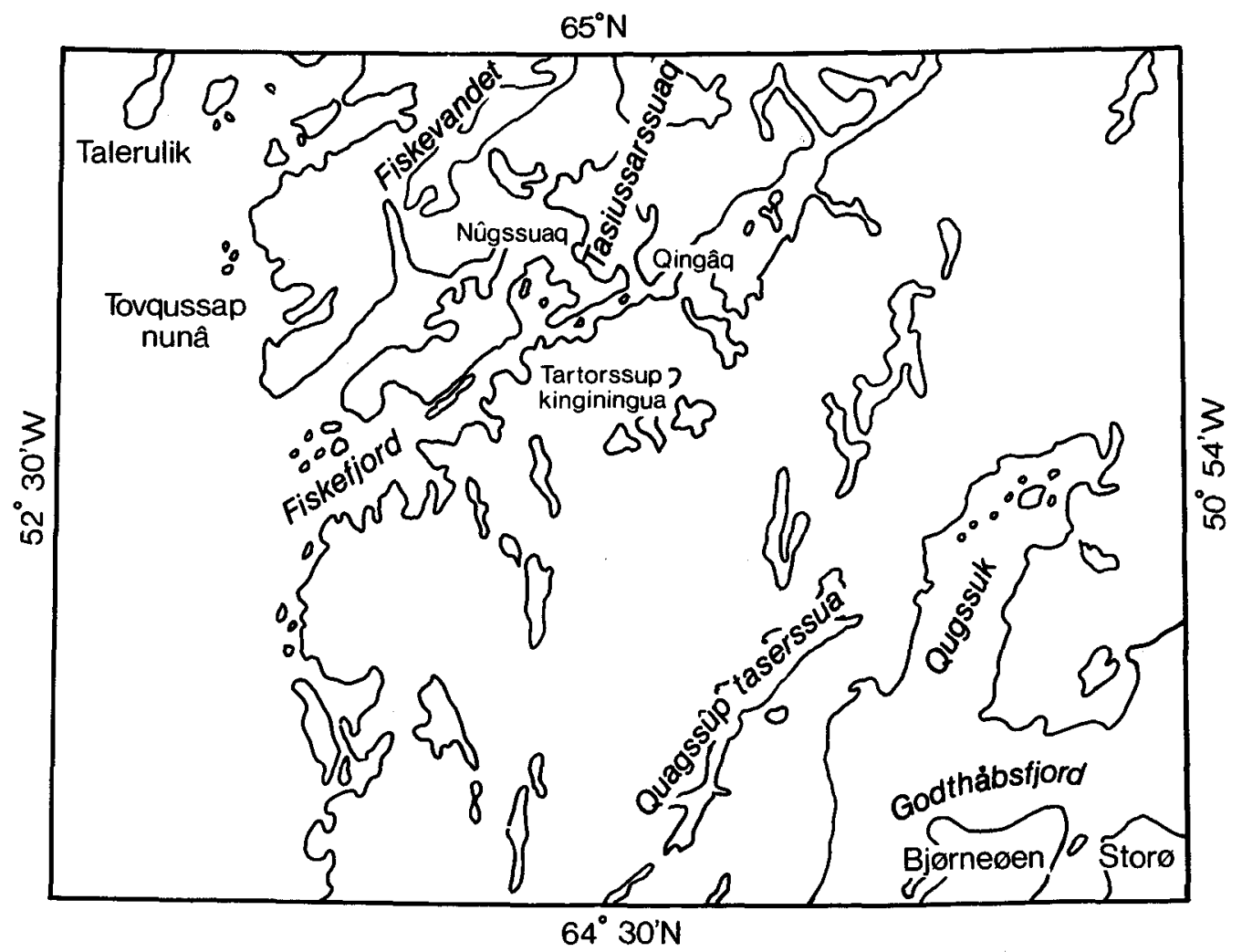

Fig. 1. Index map of the Fiskefjord map sheet area showing areas of mapping in 1986. 
scheelite province in Malene rocks in southern West Greenland (Appel, 1984) extends northwards into the granulite facies and retrograded supracrustal rocks in the Fiskefjord area (P. W. U. Appel, personal communication, 1986).

\section{General geology}

The Fiskefjord area consists of a series of late Archaean dioritic, tonalitic, trondhjemitic and granitic gneisses, equivalent to the Nûk gneisses in the Godthåbsfjord area, which contain coherent tracts and widespread inclusions of Malene-type supracrustal rocks. The Fiskefjord area is characterised by rocks with metamorphic disequilibrium parageneses, partially retrograded from granulite facies conditions; however, the extreme north-western part of the area covered in 1986 seems to form an exception to this rule (see below).

The mapping confirmed the lithological chronology and structural evolution in the Fiskefjord area established by Garde $(1984,1986)$, to which the reader is referred. Grey tonalitic gneisses predominate in most of the areas mapped adjacent to Fiskefjord. However, on both sides of central to outer Fiskefjord and west of Tasiussarssuaq there are coherent units and inclusions of mafic (metadioritic) gneiss within the grey gneisses. Some of these mafic gneisses are structurally continuous with, and lithologically similar to, the metadioritic gneisses predominating in Nordlandet and in the southern part of the map sheet area.

Pinkish grey sugary granitic gneisses, presumably retrograded from granulite facies but younger than the grey gneisses, are pervasive between Fiskevandet and Tasiussarssuaq around $64^{\circ} 57^{\prime} \mathrm{N}, 51^{\circ} 48^{\prime} \mathrm{W}$. Granitic gneisses also occur at Tartorssup kinginíngua south of Fiskefjord. In the area south-west of the lake Quagssûp taserssua, which consists of granulite facies mafic gneiss, there are local spots pervaded by sheets of granitic rocks. Within a few metres from the granite contacts the mafic gneiss is bleached and retrograded and apparently metasomatised by the granites, which therefore seem to postdate the granulite facies metamorphism. In the process all former structure in the mafic gneiss such as nebulitic banding and quartz-plagioclase veining is completely lost, and locally replaced by a new foliation which sometimes affects the granites as well.

Reconnaissance mapping was carried out by helicopter on the northern parts of Bjørneøen and Storø, which mainly consist of Nûk gneisses with intercalated Amîtsoq gneisses and Malene supracrustal rocks, and a less than $50 \mathrm{~m}$ thick anorthosite horizon at Storø. These units are continuous with those in the southern parts of the islands shown on the map $64 \mathrm{~V} .1$ Qôrqut (McGregor, 1984). In the north-eastern part of Bjørneøen large exposures of deformed Taserssuaq tonalite (Garde et al., 1983, 1986) were found this summer. These exposures are probably structurally continuous with the Taserssuaq tonalite mapped along the south coast of the peninsula between Qugssuk and Ilulialik (Garde, 1986). The Taserssuaq pluton may extend further southwards within the Qôrqut map sheet area towards Nuuk.

\section{Structure in the central Fiskefjord area}

The structure in the central Fiskefjord area is still somewhat incompletely known and a more precise structural analysis must await further mapping. The mapping so far has revealed the general features of the structural history, including polyphase folding during successive episodes with different fold styles, and a final phase of faulting. 

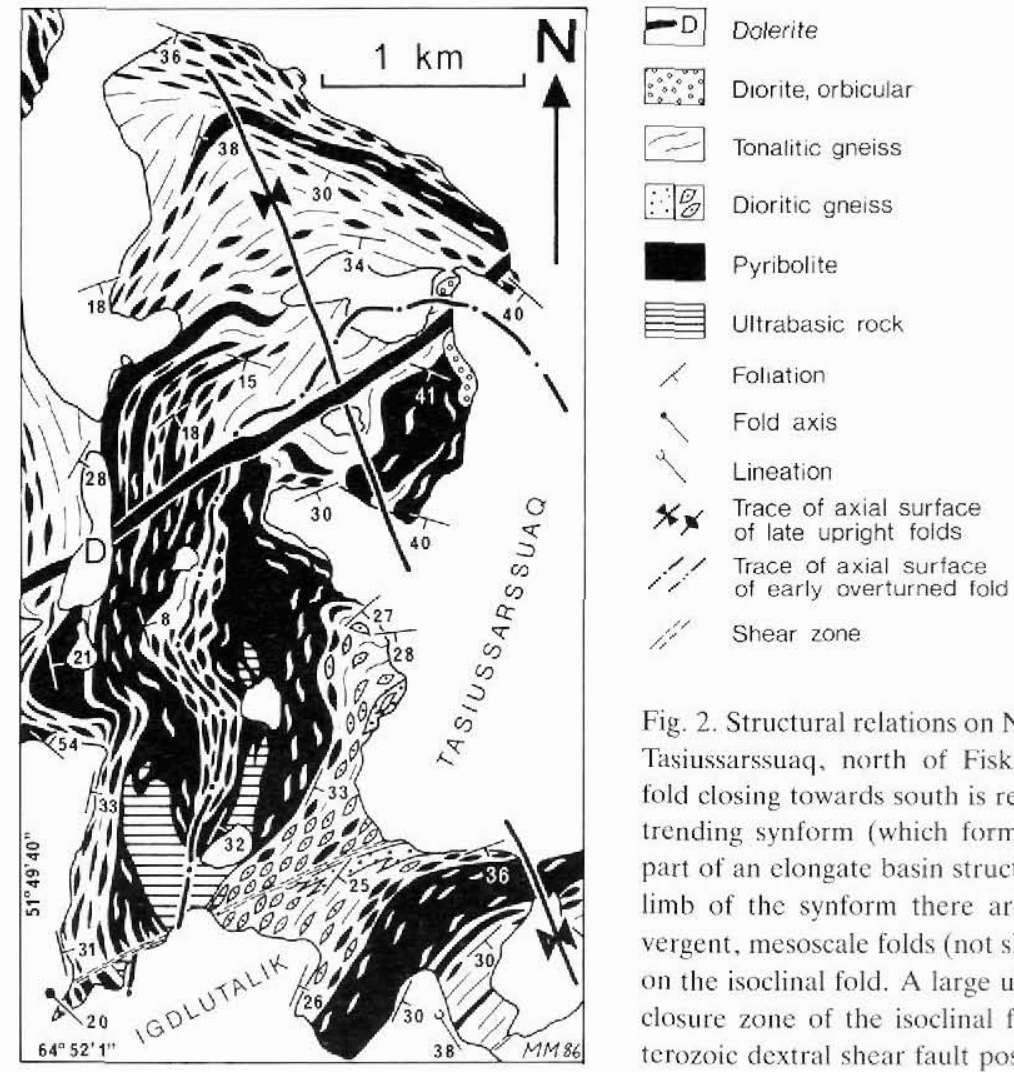

Fig. 2. Structural relations on Nûgssuaq, south-west Tasiussarssuaq, north of Fiskefjord. An isoclinal fold closing towards south is refolded by a NW-SE trending synform (which forms the north-western part of an elongate basin structure). In the western limb of the synform there are SE-plunging, NEvergent, mesoscale folds (not shown) superimposed on the isoclinal fold. A large ultrabasic body in the closure zone of the isoclinal fold is cut by a Proterozoic dextral shear fault postdating the folding.

Most small-scale fold structures seen in the field probably belong to late phases of deformation. Most measured fold axes show gentle to moderate plunges in north-western or south-eastern directions. In the central Fiskefjord area these axes belong to tight to open folds mostly with moderately SW-dipping axial surfaces. In other areas, e.g. along the outer coast, the axial surfaces may dip steeply. Although some of these folds may represent reoriented folds preserved from earlier episodes of folding, it appears that they generally belong to a late episode in the regional fold chronology. The style and orientation of folds from this episode indicate a correlation with the Pâkitsoq phase on Tovqussap nunâ (Berthelsen, $1960)$.

Another structural feature in the Fiskefjord area is a pattern of domes and basins often measuring several kilometres across. Some of these show a clear NNW-SSE elongation while others are more or less circular in shape. In certain areas, as around Tasiussarssuaq, elongated domes and basins sometimes seem to be axial culminations and depressions of NNW-SSE oriented regional antiforms and synforms.

Small-scale folding has apparently not accompanied the dome and basin formation which arches the earlier fold interference pattern into open folds. However, it may be difficult to decide if some of the NW-SE oriented folds belong to the episode described above or are at- 
tached to the dome and basin episode, since the axial directions of the two episodes are roughly parallel. Also the relation between the NW-SE oriented fold episode and the dome and basin formation in central Fiskefjord is not yet clear, although Berthelsen (1960) has demonstrated that the latter preceded the former on Tovqussap nunâ.

Both of the two episodes mentioned above have affected and refolded major folds that were formed during (at least) two earlier episodes of folding. Figs 2 and 3 show two examples of this relationship from the central Fiskefjord area. On Nûgssuaq in the south-western part of Tasiussarssuaq (fig. 2) a large isoclinal fold is refolded into a SSE-plunging synformal (basin) structure. Furthermore, both limbs of the isocline are refolded by NE-verging, SEplunging mesoscale folds west of the synformal axis. The mesoscale folds belong to the NW-SE oriented fold episode mentioned earlier. A large ultrabasic body is situated at the closure of the isoclinal fold as is frequently the case.

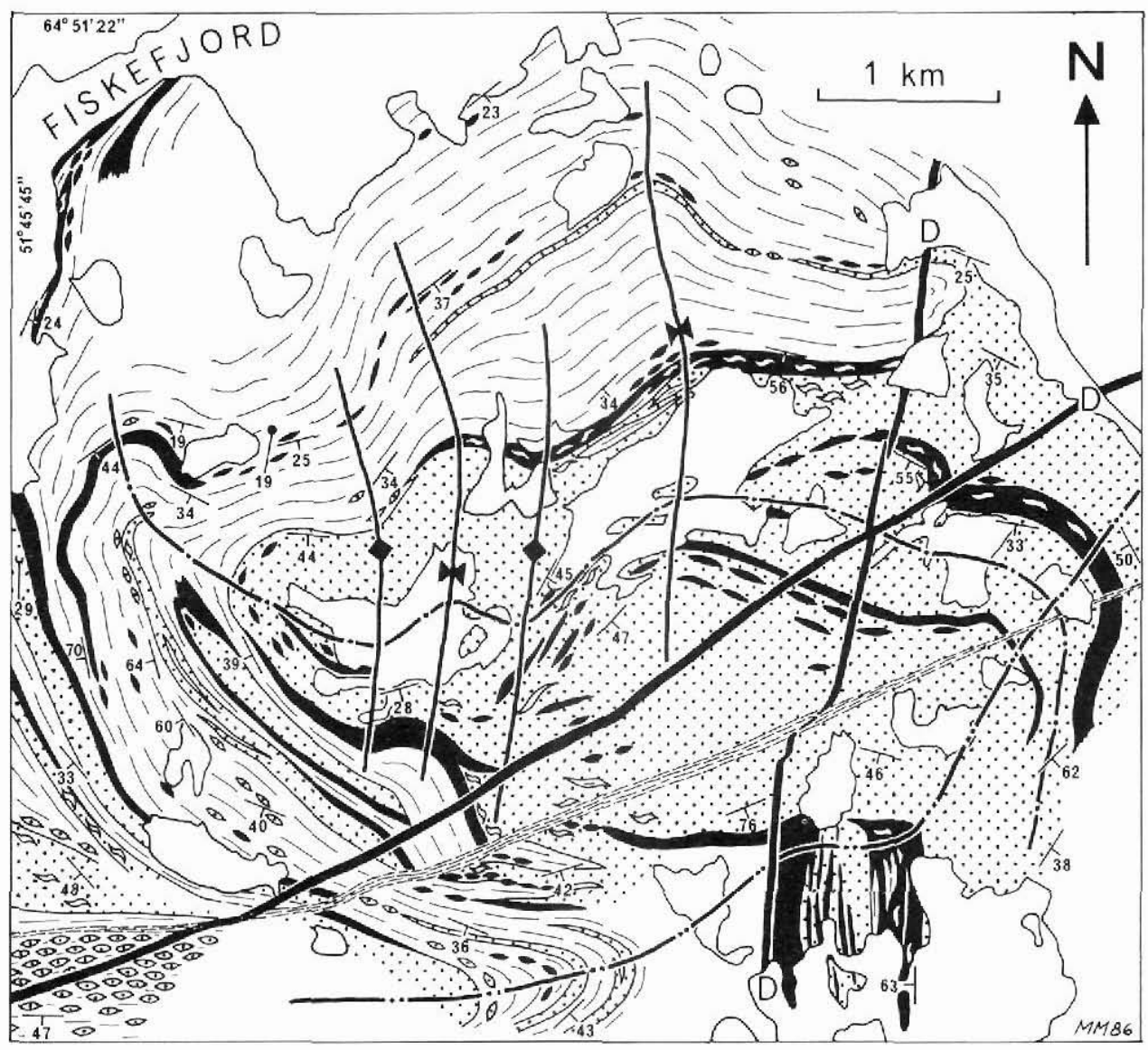

Fig. 3. Fold interference patterns south-cast of Fiskefjord opposite Qingâq. A large isoclinal fold closing towards west is refolded by another large isoclinal fold trending NE-SW. Both of these are refolded by N-S trending open folds. A narrow Proterozoic shear-zone trends WNW-ESE parallel to Fiskefjord and postdates both the latest open folds and intrusion of dolerite dykes. Legend as in fig. 2 . 
Another example comes from an area south-east of Fiskefjord, opposite to Qingâq (fig. 3 ). In this area a large isoclinal fold is refolded by another isoclinal fold into an interference pattern which was refolded once more by gentle to open $\mathrm{N}-\mathrm{S}$ oriented folds that probably belong to the dome and basin forming episode.

Large-scale interference patterns thus show that both the Malene-type supracrustal rocks and the intruded Nûk-type gneisses in the Fiskefjord area were affected by at least four episodes of regional folding. The first two episodes produced isoclinal folds, succeeded by two episodes which produced more upright, open folds and dome and basin structures that were oriented NW-SE and NNW-SSE, respectively. A still earlier fold episode may be inferred from occasional occurrences of supracrustal inclusions that show internal fold structures in otherwise non-folded gneisses. This suggests that the Malene-type supracrustal sequence was folded even before it was intruded by the gneiss protoliths.

At various places the supracrustal rocks and the grey gneisses alternate in conspicuously banded sequences, which form zones some tens of metres to one or two kilometres across, and of great extension along strike. The width of the individual bands is commonly in the centimetre to decimetre (sometimes 1 metre) scale. This strong banding is interpreted as a tectonic feature which has originated from strong ductile shear deformation of an original inclusion pattern along localised zones in the rock sequence. Since the banding is deformed by both of the two early isoclinal fold episodes, the banding must be a very early feature and is possibly evidence for emplacement of Nûk-type rocks into the Malene-type supracrustals during strong lateral shearing as proposed by Bridgwater et al. (1974).

\section{Finnefjeld gneiss}

The Finnefjeld gneiss (Berthelsen, 1950, 1957, 1962) is a large gneiss pluton in the southern Sukkertoppen district, which incorporates the island Talerulik at the north-western corner of the Fiskefjord map sheet area (Berthelsen, 1962, Plate 1). The Finnefjeld gneiss is composed of several generations of homogeneous grey biotite gneiss in amphibolite facies.

Several localities of Finnefjeld gneiss were visited at the coast of Uivfaq around $65^{\circ} 05^{\prime} \mathrm{N}$, $52^{\circ} 15^{\prime} \mathrm{W} \mathrm{c.} 10 \mathrm{~km}$ north of the northern map sheet boundary, where at least four successive phases of gneiss could be recognised. There are two early phases of medium-grained, dark grey and grey tonalitic gneiss with a characteristic coarse patchy gneissic texture formed by elongated biotite-plagioclase aggregates $1-2 \mathrm{~cm}$ in size. The third generation is a fine- to medium-grained light grey gneiss with evenly distributed fine-grained biotite, which is in turn succeeded by a fourth phase of homogeneous white leucocratic medium- to coarse-grained gneiss presumably of granitic composition. Whereas phases 1-3 of the Finnefjeld gneiss predate a pronounced NNE- to NE-trending steep to vertical foliation with accompanying small-scale SSW-plunging isoclinal folds, the fourth white leucocratic phase is syntectonic, intruded as sheets roughly parallel to foliation in its host gneisses but with clearly discordant margins.

At Talerulik the fine-grained phase three gneiss predominates, cut by thin sheets of white phase four gneiss, which locally grades into pegmatite. Along the western side of Talerulik there is a conspicuous series of variegated supracrustal rocks including (granulite facies) pyribolites and garnet-rich metasedimentary rocks. The supracrustal rocks are intruded by the Finnefjeld gneiss, and both units suffered strong deformation under amphibolite facies con- 
ditions with development of tight to isoclinal folds, and foliation parallel to axial surfaces. This foliation is discordant to an earlier (granulite facies) foliation which can only be recognised in the supracrustal rocks. Amphibolite facies recrystallisation with elimination of hypersthene and production of garnet can locally be observed in the supracrustal rocks along closely $(1-5 \mathrm{~cm})$ spaced surfaces parallel to axial surface foliation in immediately adjacent Finnefjeld gneiss. Inspection of thin sections is required to determine exactly what (amphibolite facies) reactions have taken place in the supracrustal rocks.

\section{Post-tectonic orbicular diorite}

Both north and south of Fiskefjord post-tectonic diorites have been found. The diorites are inclined sheets which reach lengths of $c .4 \mathrm{~km}$ and thicknesses of $c .100 \mathrm{~m}$. A brief description of the best exposures south of the fjord follows. Around $64^{\circ} 46^{\prime} \mathrm{N}, 51^{\circ} 48^{\prime} \mathrm{W}$ several elongated exposures of diorite form a curved line trending $040-070^{\circ}$ and may be connected at depth. The contacts are inclined $c .45^{\circ}$ to the south-east and appear very sharp when viewed from a distance, but the boundaries actually consist of $c$. 1-3 m wide gradational hybrid zones intermediate between the diorite and host light grey gneiss. The diorite is never migmatised nor agmatised by the enclosing gneiss. At a locality where the diorite cuts mafic supracrustal rocks it contains angular metre-sized rafts of the latter close to the inferred (unexposed) contact. The diorite is occasionally cut by less than $5 \mathrm{~cm}$ thick planar pegmatite sheets with sharp boundaries. An MD dyke cuts one of the diorites with a chilled dyke margin exposed. The diorite bodies are post-tectonic and were apparently intruded into solidified but still hot country rocks (as indicated by the hybrid contact zones), presumably at the close of the Archaean.

Although the diorites often form small hills, they are generally poorly exposed as they readily weather into coarse brown gravel that obscures the bedrock. The diorites sometimes have a characteristic, coarse orbicular texture formed by 1-2 cm large aggregates of small plagioclase crystals set in a medium-grained matrix of plagioclase and mafic minerals. This texture strongly resembles that of a small body of orbicular diorite at Tovqussaq nunâ described by Berthelsen (1960), which is considered to belong to the same family of diorites as those found this summer in the central Fiskefjord area.

\section{References}

Appel, P. W. U. 1984: Tungsten mineralisation in the Godthåb area, West Greenland. Rapp. Grønlands geol. Unders. 120, 51-54.

Berthelsen, A. 1950: A Pre-Cambrian dome structure at Tovqussaq, West-Greenland. Meddr dansk geol. Foren. 11, 558-572.

Berthelsen, A. 1957: The structural evolution of an ultra- and polymetamorphic gneiss complex, West Greenland. Geol. Rdsch. 46, 173-185.

Berthelsen, A. 1960: Structural studies in the Pre-Cambrian of West Greenland; part II: Geology of Tovqussap nunâ. Meddr Grønland 123(1), 223 pp. (Also Bull. Grønlands geol. Unders. 25.)

Berthelsen, A. 1962: Structural studies in the Pre-Cambrian of West Greenland; part III: Southern Sukkertoppen district. Meddr Grønland 123(2), 47 pp. (Also Bull. Grønlands geol. Unders. 31.)

Bridgwater, D., McGregor, V. R. \& Myers, J. S. 1974: A horizontal tectonic regime in the Archaean of Greenland and its implications for early crustal thickening. Precambrian Res. 1, 179-197. 
Garde, A. A. 1984: Field work between Fiskefjord and Godthåbsfjord, southern West Greenland. Rapp. Grønlands geol. Unders. 120, 45-50.

Garde, A. A. 1986: Field observations around northern Godthåbsfjord, southern West Greenland. Rapp. Grønlands geol. Unders. 130, 63-68.

Garde, A. A. \& McGregor, V. R. 1982: Mapping in the Fiskefjord area, southern West Greenland. Rapp. Grønlands geol. Unders. 110, 55-57.

Garde, A. A., Hall, R. P., Hughes, D. J., Jensen, S. B., Nutman, A. P. \& Stecher, O. 1983: Mapping of the Isukasia sheet, southern West Greenland. Rapp. Grønlands geol. Unders. 115, $20-29$.

Garde, A. A., Larsen, O. \& Nutman, A. P. 1986: Dating of late Archaean crustal mobilisation north of Qugssuk, Godthåbsfjord, southern West Greenland. Rapp. Grønlands geol. Unders. 128, 23-36.

McGregor, V. R. (comp.) 1984: Geological map of Greenland 1:100 000, Qôrqut, 64 V.1 S. Copenhagen: Geol. Surv. Greenland.

M. $M$, Institut for Almen Geologi, $\emptyset$ ster Voldgade 10 DK-1350 Copenhagen $K$, Denmark.

\title{
Scheelite occurrences in granulite facies metamorphosed supracrustals, West Greenland
}

\author{
Peter W. Uitterdijk Appel
}

In 1982 the first traces of scheelite in heavy mineral concentrates from stream sediments were found in the Godthåbsfjord area. Subsequently a quite extensive scheelite mineralisation has been found in the Malene supracrustal rocks (Appel, 1986a). During 1985 a regional stream-sediment sampling programme was carried out covering an area of about $30000 \mathrm{~km}^{2}$ within the Godthåb area. As a result of this programme scheelite was found in most of the streams draining Malene supracrustal rocks (Appel, 1986b). One of the areas which appeared to be interesting is the Sermilik area $c .75 \mathrm{~km}$ south of Nuuk. In this area several streams with high contents of scheelite were found. The area has been subject to granulite facies metamorphism and a major granitic intrusion emplaced. Both events might have caused extensive mobilisation and subsequent upgrading of stratabound scheelite mineralisation. The supracrustals are situated at the shore of a small fjord, where ice rarely causes problems for shipping. The alpine topography, with near vertical cliffs, poses an obstacle for prospecting.

The present paper describes only field observations. Laboratory work is confined to X-ray identification of scheelite in some of the heavy mineral concentrates and in a few rock samples. 